of school and university play at present a dominating rôle in the science taught at schools, and the influence is not all to the good. The main object of schools seems to be to produce scholarships, and the main objects of universities to produce research workers. Such objects have a cramping effect on the whole organisation of science teaching. In the first place, very many boys, from public and secondary schools never go near a university; and secondly, only a relatively small proportion of students who do go there become first-class research workers. The really good research worker survives under almost repressive conditions, and is often hampered by the people whose job it is to teach him. When research is so badly paid it seems a pity that it should be held up as an ideal to any students but the very best, especially since progress in the applications of science only partly keep step with the rate at which discoveries are made, as the modern system of agriculture in England shows very clearly.

The great mass of boys and students do not possess the research mind, and no amount of training in method will give it to them. In their scientific edueation they slowly, and often painfully, acquire some technical knowledge, most of which is of no further value when the examination is over. Pushing them hard merely dulls their wits and gives them a bad taste for science. They lack the imagination required for research, and the technical ability to handle apparatus with real success. They do, how ever, make up the bulk of those people who control our complex industrial system, because they possess general ability and character for leadership.

My personal complaint is that, while science has now illuminated the western world for some hundred years, no bold attempt has yet been made to reorganise and direct our social system in keeping with it. It has been given no cultural value, although it has had a profound and disturbing effect on all previous types of culture and resthetic ideals. As a new force it yet lacks 'official' recognition except in Central and Eastern Europe, where it is beginning to affect art, literature, and possibly music. The coming of science and industry has completely changed the world. It has given us social, economic, and international, problems which cry aloud for scientific solutions; but unless the mass of the people is trained in the atmosphere of science, it will persist in attempting to solve these problems on traditional medieval lines. In this respect there is an enormous field for our educational institutions, which still waste time teaching the difference between density and specific gravity, and the number of stamens in a flower, in jargon which has been invented to make the task difficult. At present science as taught, with exceptions of course, is in the 'date' stage of history or the 'capes and peaks' stage of geography. It will only gain respect as an educational medium when it has set up cultural ideals which are attractive to all types of thinkers. Of course, evolution in the right direction is inevitably taking place in spite of efforts to prevent it, but we could accelerate the change considerably if we really pulled together.

Eton College, Windsor, Mar. 28

R. Weatherall.

\section{Beats by High-Frequency Interruption of Light.}

For some time past we have been engaged in developing a compact laboratory method of measuring the velocity of light by utilising the Kerr electrooptic effect in nitrobenzene for obtaining very rapid intermittence in a light beam. The restoration of light by nitrobenzene (put between crossed Nicols)

No. 3050, Vor. 121] under electric stimulus is comparatively large and is almost instantaneous - the lag being of the order of $10^{-10} \mathrm{sec}$.

The Kerr cell employed was of the type developed by Karolus (for the Telefunken-Karolus system of pieture transmission), and was kindly supplied to us by the Telefunken Company.

As in all such experiments for velocity determination the light has to be passed twice through the interrupting mechanism, it was thought desirable, as a preliminary step, to see if sufficient light would come out through two cells in succession. After overcoming considerable experimental difficulties, and by using sunlight as source, we were able to get sufficiently intense interrupted light passing out of the second cell. To test if the interruptions were taking place properly, the sunlight was focused on the first Karolus cell placed between crossed Nicols and excited by a valvemaintained oscillator of frequency about $10^{6}$ cycles per second. The restored intermittent light was received on a second cell excited by another oscillator differing in frequency from the first by a few hundred cycles. The emergent light, after passing through another Nicol, was received in a fall-plate camera, and the slow light beats resulting from the interference of the high-frequency interruptions in the two cells were photographed. Fig. 1 is a reproduction of such a photograph magnified three diameters.

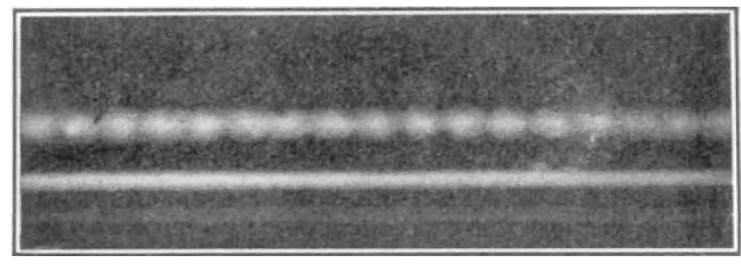

FIG. 1.

The frequency of the light beat was apparently double the frequency of the heterodyne beat note as heard in a telephone. We attempted to detect the light beats visually by bringing down the beat frequency to two or three per second. In this we were unsuccessful, obviously due to the forced synchronisation of the two oscillations (as noticed by Appleton, Proc. Camb. Phil. Soc., vol. $21 ; 1922)$ taking place long before the difference in the frequencies becomes sufficiently small to make visual observation possible.

This beat method can be adapted to study the highfrequency intermuption of light by resonating quartz, which Prof. Kerr Grant tried to photograph at a frequency of 144 kilo-cycles per second, but was unsuccessful (NATURE, Oct. 22, 1927). It is only necessary to replace the first or the second Karolus cell by the resonating quartz. In his note, Prof. Kerr Grant suggests the employment of resonating quartz for obtaining interrupted light of very high frequency up to ten million per second. We are doubtful if this is practically possible. The thickness of a quartz crystal cut and ground to this frequency is very small (only a fraction of a millimetre along the electrical axis and normal to the optic axis, for it is about one millimetre even for a million-cycle) and it would be exceedingly difficult, if not impossible, to make any observation by passing light in a direction parallel to the optic axis.

University College of Science,

S. K. MITRA.

D. BANERJI.

92 Upper Calcutta Road,

Calcutta, India, Feb. 16. 